Article

\title{
Space-Time Machine Learning Models to Analyze COVID-19 Pandemic Lockdown Effects on Aerosol Optical Depth over Europe
}

\author{
Saleem Ibrahim *, Martin Landa, Ondřej Pešek, Karel Pavelka and Lena Halounova
}

check for

updates

Citation: Ibrahim, S.; Landa, M.; Pešek, O.; Pavelka, K.; Halounova, L. Space-Time Machine Learning Models to Analyze COVID-19 Pandemic Lockdown Effects on Aerosol Optical Depth over Europe. Remote Sens. 2021, 13, 3027.

https://doi.org/10.3390/rs13153027

Academic Editors: Maria João Costa and Daniele Bortoli

Received: 22 June 2021

Accepted: 29 July 2021

Published: 2 August 2021

Publisher's Note: MDPI stays neutral with regard to jurisdictional claims in published maps and institutional affiliations.

Copyright: (c) 2021 by the authors. Licensee MDPI, Basel, Switzerland. This article is an open access article distributed under the terms and conditions of the Creative Commons Attribution (CC BY) license (https:// creativecommons.org/licenses/by/ $4.0 /)$
Department of Geomatics, Faculty of Civil Engineering, Czech Technical University in Prague, 16629 Prague, Czech Republic; martin.landa@fsv.cvut.cz (M.L.); ondrej.pesek@fsv.cvut.cz (O.P.); karel.pavelka@fsv.cvut.cz (K.P.); lena.halounova@fsv.cvut.cz (L.H.)

* Correspondence: saleem.ibrahim@fsv.cvut.cz
Abstract: The recent COVID-19 pandemic affected various aspects of life. Several studies established the consequences of pandemic lockdown on air quality using satellite remote sensing. However, such studies have limitations, including low spatial resolution or incomplete spatial coverage. Therefore, in this paper, we propose a machine learning-based scheme to solve the pre-mentioned limitations by training an optimized space-time extra trees model for each year of the study period. The results have shown that our trained models reach a prediction accuracy up to $95 \%$ when predicting the missing values in the MODIS MCD19A2 Aerosol Optical Depth (AOD) product. The outcome of the mentioned scheme was a geo-harmonized atmospheric dataset for aerosol optical depth at $550 \mathrm{~nm}$ with $1 \mathrm{~km}$ spatial resolution and full coverage over Europe. As an application, we used the proposed machine learning based prediction approach in AOD levels analysis. We compared the mean AOD levels between the lockdown period from March to June in 2020 and the mean AOD values of the same period for the past 5 years. We found that AOD levels dropped over most European countries in 2020 but increased in several eastern and western countries. The Netherlands had the most significant average decrease in AOD levels (19\%), while Spain had the highest average increase (10\%). Moreover, we analyzed the relationship between the relative percentage difference of AOD and four meteorological variables. We found a positive correlation between AOD and relative humidity and a negative correlation between AOD and wind speed. The value of the proposed prediction scheme is further emphasized by taking into consideration that the reconstructed dataset can be used for future air quality studies concerning Europe.

Keywords: aerosol optical depth; CAMS; COVID-19; machine learning; MODIS

\section{Introduction}

The Severe Acute Respiratory Syndrome-COronaVIrus Diseases 2019 (SARS-COVID19) pandemic made humanity reconsider how to adapt their daily activities. By late June 2020, the EU average infection rate was around 160 per million inhabitants [1]. In general, most European countries started applying restrictions in March 2020. These restrictions included lockdown, contain, various kinds of curfew, mandatory face masks, etc. By 18 March 2020, more than 250 million people in Europe were in lockdown [2].

Despite the unfortunate losses in human lives and the economy, there could be a bright side to this pandemic when it comes to air quality. Some studies showed that air quality has improved under the applied restrictions. For example, only two weeks of lockdown reduced urban air pollution in Spain, with essential differences among pollutants. The most considerable reduction was in black carbon and Nitrogen Dioxide $\left(\mathrm{NO}_{2}\right)$ by $45-51 \%$ [3]

According to data released in 2019-2020 by the National Aeronautics and Space Administration (NASA) and the European Space Agency (ESA), $\mathrm{NO}_{2}$ was reduced up to $30 \%$ in some regions that were highly affected by COVID-19 lockdowns such as Wuhan in 
China, Italy, Spain, and the USA [4]. Similar results were found in Poland when comparing air quality observations for the year 2020 in five major cities with the same time periods as in the previous two years. In addition, AOD concentrations were reduced in April and May of 2020 by nearly $23 \%$ and $18 \%$ as compared to 2018-2019 [5].

During the lockdown in China, there was a significant drop in $\mathrm{NO}_{2}(-37 \%), \mathrm{SO}_{2}$ $(-64 \%)$, and AOD $(-8 \%)$ for the year 2020, when compared with the 11 year mean average (2009-2019) [6]. Another study of the eastern part of China, where AOD levels are usually high (AOD > 0.7), showed that the emission of pollutants in the first three months of 2020 has decreased when compared to the same period of the previous year [7]. In India, the AOD level was greatly decreased ( $45 \%)$ during the COVID-19 lockdown periods compared to the mean AOD level in the previous 20 years [8]. Similarly, significant reductions in black carbon concentration $(\sim 8.4 \%)$ and AOD $(10.8 \%)$ were observed in southern India during the first lockdown period (25 March-14 April 2020) when compared to the pre-lockdown period (1-24 March 2020) over the selected measuring location [9].

In this study, we focused on AOD, which is defined as a measure of the columnar atmospheric aerosol content. High AOD concentrations have a negative impact on all living things by affecting the respiratory system and reducing naked eye visibility. AOD is measured either from ground-based stations or retrieved by satellites measurements. AOD satellite-based products provide a vast spatial coverage compared to the limited number of ground stations [10].

Due to the correlation between AOD and particulate matter (PM), AOD satellite products are commonly used to retrieve surface PM [11-13]. This justifies the increasing interest in AOD satellite products. Many sensors retrieve AOD at different spatial and temporal resolutions [14], such as the Total Ozone Mapping Spectrometer (TOMS) [15], the Ozone Monitoring Instrument (OMI) [16], the Sea-viewing Wide Field-of-view Sensor (SeaWiFS) [17], the Geostationary Operational Environmental Satellite (GOES) [18], the Advanced Himawari Imager (AHI) [19], the Multi-angle Imaging SpectroRadiometer (MISR) [20], and the widely used Moderate Resolution Imaging Spectroradiometer (MODIS) which we used in our study.

MODIS instrumentations have been carried on both the Terra and Aqua satellites in sun-synchronous polar orbits, since 1999 and 2002, respectively. They can record the earth's surface reflectance and emittance with a $2330 \mathrm{~km}$ swath every one to two days [21]. MODIS measures 36 spectral bands between 0.4 and $14.4 \mu \mathrm{m}$ wavelengths at many different spatial resolutions that provide a great opportunity to study the aerosol thickness and parameters characterizing aerosol size from space with good accuracy and on a worldwide scale.

MODIS provides various AOD products based on different aerosol retrieval algorithms. The most common algorithms are the Dark Target (DT) [22,23], the Deep Blue (DB) [24,25], and the Multi-Angle Implementation of Atmospheric Correction for MODIS (MAIAC) [26] which is the algorithm used to generate the MODIS MCD19A2 product with $1 \mathrm{~km}$ spatial resolution.

However, AOD satellite-based products have a great number of gaps due to cloud cover and snow reflectance. An analysis of the spatial and temporal distribution of clouds retrieved by MODIS over 12 years of continuous observations from the Terra satellite and over 9 years from the Aqua satellite showed that clouds cover $\sim 67 \%$ of the earth's surface worldwide and $\sim 55 \%$ over land [27]. To solve this issue, it has become common to use machine learning and deep learning algorithms in developing models that fill the gaps in satellite-based products either by removing the clouds [28], applying spatiotemporal interpolation [29], or merging different sources of data to predict gaps-free images [30]. Therefore, in this study, we propose a machine learning-based scheme to fill the gaps in MODIS MAIAC AOD retrievals and to generate daily, full coverage, high-resolution AOD maps over Europe. Such maps will minimize time series analysis bias and uncertainty while investigating the influence of COVID-19 lockdown on AOD levels. 


\section{Material and Data}

\subsection{Study Area and Period}

The study area is shown in Figure 1. It includes the "Continental EU," hence EEA (European Economic Area), and the United Kingdom, Switzerland, Serbia, Bosnia and Herzegovina, Montenegro, Kosovo, North Macedonia, and Albania [31]. In this paper, we refer to the area of study as "Europe" located inside this coordinates box $26^{\circ} \mathrm{W}, 72^{\circ} \mathrm{N}, 42^{\circ}$ $\mathrm{E}$, and $36^{\circ} \mathrm{S}$. The total study area covers $13,391,504$ of $1 \mathrm{~km}$ grid cells; 5,450,009 of the total cell number are located over land. The study period covers the months of March-June from the years 2015-2020.

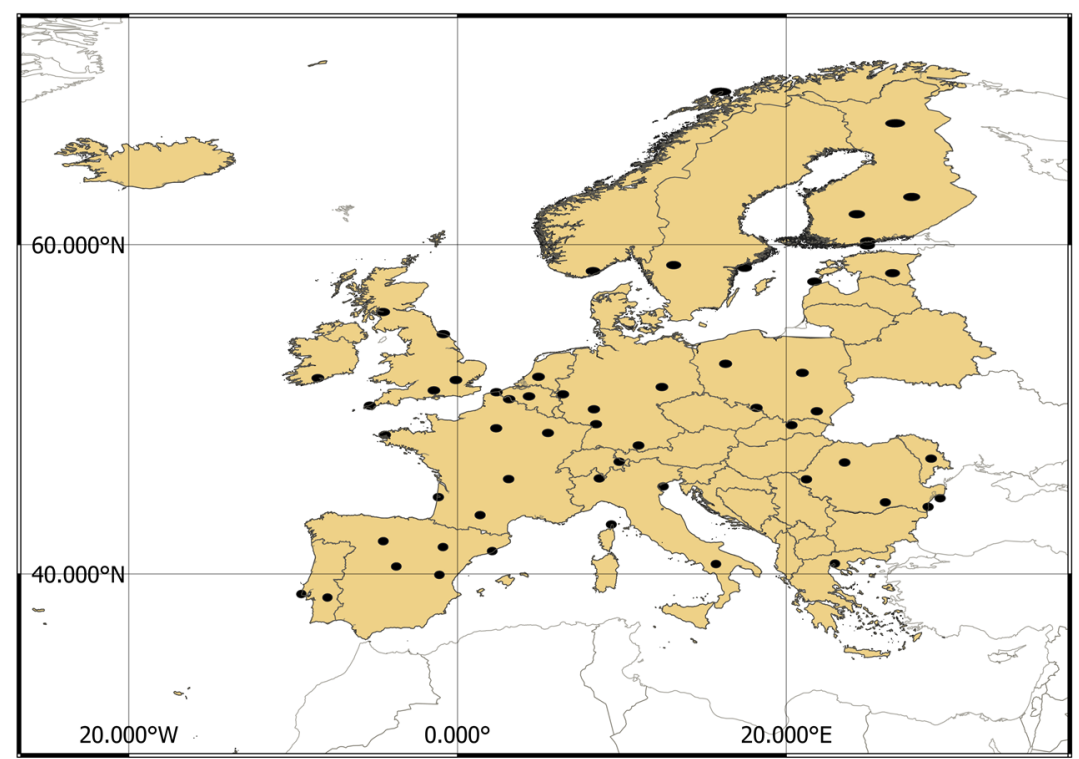

Figure 1. The study area with AERONET stations shown as black dots.

\subsection{Data}

In this section, we summarize different data used throughout our study.

\subsubsection{MODIS Data}

MCD19A2 daily product from MODIS collection 6 was released and made publicly available on 30 May 2018. It was generated from both the Aqua and Terra satellites and delivered in Hierarchical Data Format [26]. MCD19A2 has a $1 \mathrm{~km}$ spatial resolution and uses the MAIAC algorithm that utilizes time series (TMS) analyses, a set of image-based and pixel processing to enhance the precision of cloud recognition, AOD, and other atmospheric rectification [32,33]. Daily MODIS MCD19A2 data were downloaded, and two science datasets (SDS) were extracted; AOD green band (at $550 \mathrm{~nm}$ ) and AOD quality assurance layer (AOD_QA), which was used to retrieve only pixels with the best quality. We created daily mosaics that cover the study area.

\subsubsection{Copernicus Atmosphere Monitoring Service (CAMS) Data}

In this study, modeled AOD at $550 \mathrm{~nm}$ data with $80 \mathrm{~km}$ spatial resolution produced by the European center for medium-range weather forecasts Atmospheric Composition Reanalysis 4 (EAC4) was used to fill the gaps in the MODIS MCD19A2 product. Reanalysis merges model data with worldwide observations into a compatible dataset generated by an atmospheric model that uses the laws of physics and chemistry. EAC4 estimates modeled AOD every $3 \mathrm{~h}$ using the $4 \mathrm{D}$-Var assimilation method [34].

\subsubsection{Digital Elevation Model}

The elevation of the grid cells was added as a land predictor in our study. The Japan Aerospace Exploration Agency (JAXA) provides a worldwide digital surface model for 
scientific research and other geospatial services. It provides a horizontal resolution $(\sim 30 \mathrm{~m})$ by the Panchromatic Remote-sensing Instrument for Stereo Mapping (PRISM), which was carried on the Advanced Land Observing Satellite "ALOS" [35]. Data was accessed in March 2021 from (https:/ / www.eorc.jaxa.jp/ALOS/).

\subsubsection{Ground-Based AOD Data}

NASA's Aerosols Robotic Network (AERONET) is considered one of the most reliable aerosol networks [36]. AERONET measures direct solar and sky radiance in various channels every $15 \mathrm{~min}$ at the local point to compute columnar AOD at intervals from 350 to $1020 \mathrm{~nm}$ with low expected uncertainties ranging between 0.01 to 0.02 under cloud-free conditions [37]. There are several categories of AERONET data: level 1.0 (unscreened), level 1.5 (cloud screened), and level 2.0 (cloud screened and quality assured).

In this study, AERONET level 2.0 quality assurance observations were used from 57 stations over Europe, as shown in Figure 1. Since AERONET stations do not measure AOD at $550 \mathrm{~nm}$, available measurements at the nearest two wavelengths to $550 \mathrm{~nm}$ (440 or $500 \mathrm{~nm}$ as $\lambda_{1}$ and $675 \mathrm{~nm}$ as $\lambda_{2}$ ) for each station were interpolated to $550 \mathrm{~nm}$ using the Ångström's turbidity equation represented in Equation (1) [21,38].

$$
\tau_{a}(\lambda)=\beta \lambda^{-\alpha}
$$

where $\tau_{a}(\lambda)$ is the AOD at $\lambda$ wavelength in micrometers, $\beta$ is the Angstrom's turbidity coefficient, and $\alpha$ is the band index represented in Equation (2).

$$
\alpha=-\frac{\ln \left(\tau_{a}\left(\lambda_{1}\right) / \tau_{a}\left(\lambda_{2}\right)\right)}{\ln \left(\lambda_{1} / \lambda_{2}\right)}
$$

AOD values at two different wavelengths $\lambda_{1}, \lambda_{2}$ are related by Equation (3).

$$
\tau_{a}\left(\lambda_{1}\right)=\tau_{a}\left(\lambda_{2}\right) *\left(\frac{\lambda_{1}}{\lambda_{2}}\right)^{-\alpha}
$$

\subsubsection{European Centre for Medium-Range Weather Forecasts reanalysis (ECMWF)}

ERA-5 is the fifth generation of ECMWF reanalysis for the global climate and weather. Hourly data between 10 a.m. and 2 p.m. of $U$ and $V$ wind components, total precipitation, and $2 \mathrm{~m}$ surface temperature for the months of March-June of the years 2015-2020 with $0.1^{\circ}$ spatial resolution were extracted from the ERA- 5 land hourly data. Relative humidity data between 10 a.m. and 2 p.m. at $0.25^{\circ}$ spatial resolution was extracted from the ERA-5 monthly averaged data.

All used data shown in Table 1 were reprojected to the European Terrestrial Reference System 1989 (EPSG:3035), using a $1 \mathrm{~km}$ grid cell with bilinear interpolation method for CAMS $_{\mathrm{AOD}}$ and ECMWF data and the cubic convolution for the ALOS elevation model. All values of $\mathrm{MODIS}_{\mathrm{AOD}}, \mathrm{CAMS}_{\mathrm{AOD}}$, and elevations were assigned to the closest grid cell.

Table 1. Summary of data used in this study.

\begin{tabular}{cccc}
\hline Product & Spatial Resolution & Temporal Resolution & Layer \\
\hline MODIS & $1 \mathrm{~km}$ & Daily & AOD-055 \\
MCD19A2 & $80 \mathrm{~km}$ & $3 \mathrm{~h}$ & Quality Assurance (QA) \\
CAMS & $30 \mathrm{~m}$ & - & Total aerosol optical depth at $550 \mathrm{~nm}$ \\
ALOS DSM & - & $15 \mathrm{~min}$ & Elevations \\
AERONET & $0.1^{\circ}$ & Level 2.0 \\
ECMWF & & Hourly & Wind U and V components \\
ERA-5 & $0.25^{\circ}$ & Total precipitation \\
ECMWF & Monthly & 2 m surface temperature \\
ERA-5 & & & Relative humidity \\
\hline
\end{tabular}




\section{Methodology}

In this study, we created a Geo-Harmonized Atmospheric Dataset for Aerosol optical depth (GHADA) that covers the study area. Three stages were applied to generate GHADA: first, we merged the Terra and Aqua datasets of the MODIS MCD19A2 product by applying a simple average for all pixels that passed the quality assurance criteria $\left(\mathrm{QA}_{\text {CloudMask }}=\right.$ Clear and $\mathrm{QA}_{\text {AdjacencyMask }}=$ Clear $)$ of this product. Second, we created a machine learning model for every year of the study period to predict AOD values over the study area. MCD19A2 high-quality retrievals were used as the dependent variable, and since the Terra satellite is passing locally around 10:30 a.m. and the Aqua satellite passes around 1:30 p.m., we used the modeled AOD from CAMS at the closest three times per day to the satellites passing ( 9 a.m., 12 p.m., and 3 p.m.). In addition, the spatiotemporal information for the grid cells was used as independent variables. Finally, we filled MODIS MCD19A2 gaps with the predicted AOD by merging the outputs from stages one and two. We validated the daily maps of GHADA with ground-based observation, and then we utilized this dataset to analyze how the COVID-19 lockdown has affected AOD levels over Europe during the period of March-June 2020 by comparing AOD levels for this period with the average AOD levels in the last five years (2015-2019) for the same months.

\section{Space-Time Models}

In this section, we propose a novel approach based on the Extremely Randomized Trees (ET) to predict the missing AOD values in the MODIS MCD19A2 product. First, we illustrate the principles of the ETs and discuss their suitability for the AOD prediction problem. Second, we describe in detail the proposed ET training and parameters setting for AOD prediction.

\subsection{Extra Trees Algorithm}

ET is a tree-based ensemble learning method used in our study to deal with the supervised regression and create prediction models for AOD. The idea behind ET is to strongly randomize the selection of both attributes and cut points while splitting a tree node. Unlike the widely used random forest algorithm that chooses the optimum split, ET chooses it randomly, which further reduces bias and variance. When needed, the latter algorithm creates independent randomized trees of learning sample output values [38].

The number of attributes that are randomly selected at each node $(\mathrm{K})$ and the minimum sample size for splitting a node $\left(\mathrm{n}_{\min }\right)$ are the two main parameters in the ET splitting process. This procedure is applied several times with the whole learning dataset to create an ensemble model that aggregates the predictions of the decision trees to obtain the final estimation by majority vote in classification problems and arithmetic average in regression problems. In addition to accuracy, ET has high computational efficiency [39], which is required when dealing with big data problems.

\subsection{Improved Spatiotemporal Information}

To determine the spatial and temporal correlation between MAIAC $_{\mathrm{AOD}}$ and $\mathrm{CAMS}_{\mathrm{AOD}}$, we included the following independent variables. For space, we used both the elevations of the grid cells and the great circle distance (D) between each grid cell and a reference point on a sphere identified by their latitudes and longitudes using the haversine approach (Equations (4)-(6)). For time, we used the day of the year (DOY) to calculate the radian time (Rt) for the grid cells on different days in a year to improve model handling of the seasonal cycle, Equation (7) [40].

$$
\begin{gathered}
\theta=f\left(\lambda_{\mathrm{i}, \mathrm{t}}, \varphi_{\mathrm{i}, \mathrm{t}}\right)=\text { haversin}\left(\varphi_{1}-\varphi_{2}\right)+\cos \left(\varphi_{1}\right) * \cos \left(\varphi_{2}\right) * \text { haversin}\left(\lambda_{1}-\lambda_{2}\right) \\
\text { haversin }(\theta)=\sin ^{2}\left(\frac{\theta}{2}\right)=\frac{1-\cos (\theta)}{2} \\
\mathrm{D}_{\mathrm{i}, \mathrm{t}}=\mathrm{r} * \operatorname{archaversin}(\theta)=2 * \mathrm{r} * \arcsin (\sqrt{\theta})
\end{gathered}
$$




$$
\mathrm{Rt}_{\mathrm{i}, \mathrm{t}}=\cos \left(2 \pi * \frac{\mathrm{DOY} \mathrm{i}, \mathrm{t}}{\mathrm{T}}\right)
$$

where $\theta$ is the central angle between two points in space, $\varphi_{1}$ and $\varphi_{2}$ denote the geographical latitudes in radians of two points in space, $\lambda_{1}$ and $\lambda_{2}$ denote the geographical longitudes in radians of two points in space, $r$ denotes the earth's radius in $\mathrm{km}$, DOY represents the day of the year, T represents the total number of days in the year, for every grid cell (i) on day $(\mathrm{t})$.

For each year between 2015-2020, the model was built using Equation (8).

$$
\text { AOD }_{i, t}=f\left(C A M S-9_{i, t}, \text { CAMS-12 } 2_{i, t}, \text { CAMS-15 }{ }_{i, t}, D_{i, t}, H_{i, t}, \text { Rt }_{i, t}\right)
$$

where for each grid cell (i) on day $(\mathrm{t})$ : $\mathrm{AOD}_{\mathrm{i}, \mathrm{t}}$ is the target $\mathrm{AOD}$ value, CAMS- $x$ represents the AOD value extracted from CAMS at hour $\mathrm{x}, \mathrm{D}_{\mathrm{i}, \mathrm{t}}$ represents the great circle distance, $\mathrm{H}_{\mathrm{i}, \mathrm{t}}$ represents the elevation, $\mathrm{Rt}_{\mathrm{i}, \mathrm{t}}$ represents the temporal information identified by the radian time.

\section{Results}

In this section, we present the results of the space-time ET models when predicting the MAIAC AOD values. Then we utilize these models to generate AOD maps over the study area. The validation process is also stated below. Finally, these maps were used to analyze the effects of COVID-19 lockdowns on AOD levels, as discussed in Section 5.4.

\subsection{Models}

Due to the great number of MODIS ${ }_{\mathrm{AOD}}-\mathrm{CAMS}_{\mathrm{AOD}}$ pairs over land in the study area (on average 380 million pairs per year), representative subsets consisting of $\sim 10 \%$ of the whole population (all MODIS ${ }_{\mathrm{AOD}}-\mathrm{CAMS}_{\mathrm{AOD}}$ pairs per year) were chosen using the Kolmogorov-Smirnov test to be used as learning dataset for a space-time model for each year. Then for each learning dataset, we used the $k$-fold cross-validation (where $k=5$ ) to train and validate each model. In this method, the learning dataset is divided into 5 folds, which means $80 \%$ of the pairs in the learning dataset are used as a training set for the model, and the remaining $20 \%$ are used for validation. This procedure was repeated five times to test the model on each fold. Based on learning curve results, we found that increasing the learning dataset size to $15 \%$ only increased the accuracy of the models by less than $1 \%$, and the curve reaches a plateau beyond this percentage. Therefore, to decrease the computational complexity, we used $\sim 10 \%$ of the whole population as a learning dataset. In other words, a learning dataset size of $10 \%$ is enough to reach satisfactory accuracy for each year of the study period. The optimized models (number of trees $=30$, maximum depth of the tree $=50$ ) were tested on the remaining $~ 90 \%$ (approximately 340 million pairs) of the population.

The results of the trained models for each year are summarized in Table 2. All models achieved high accuracies when predicting MAIAC AOD with a correlation of determination $\left(R^{2}\right)$ ranging between $92.5 \%$ to $95 \%$ and root mean squared errors from 0.016 to 0.02 . These high achieved accuracies with the relatively small errors show the efficiency of our spacetime models in predicting the missing AOD values and emphasize the appropriateness of exploitation modeled AOD with improved spatiotemporal information in improving satellite AOD data. 
Table 2. Results of the space-time extremely randomized models used to predict the missing AOD in the MODIS MCD19A2 product for each year of the study period.

\begin{tabular}{cccc}
\hline Year & R-Squared (\%) & RMSE & MAE \\
\hline 2015 & 95 & 0.017 & 0.011 \\
2016 & 94.3 & 0.018 & 0.011 \\
2017 & 93.8 & 0.018 & 0.011 \\
2018 & 92.5 & 0.02 & 0.012 \\
2019 & 92.9 & 0.019 & 0.012 \\
2020 & 94.1 & 0.016 & 0.010 \\
\hline
\end{tabular}

Feature importance was calculated based on the reduction in sum of squared errors whenever a variable is chosen to split. Mean importance scores were calculated for all selected input variables of the models (see Figure 2). $\mathrm{CAMS}_{\mathrm{AOD}}$ at 12:00 p.m. is the most influential variable, accounting for $\sim 33 \%$ of MODIS ${ }_{\mathrm{AOD}}$ estimates. The other two modeled AOD at 9:00 a.m. and 3:00 p.m. contributed by $18 \%$ and $24 \%$, respectively. The radian time and the great circle distance had almost the same influence (10-10.4\%). Finally, the elevation had the lowest influence, with $\sim 5 \%$ on MODIS $_{\mathrm{AOD}}$ estimates.

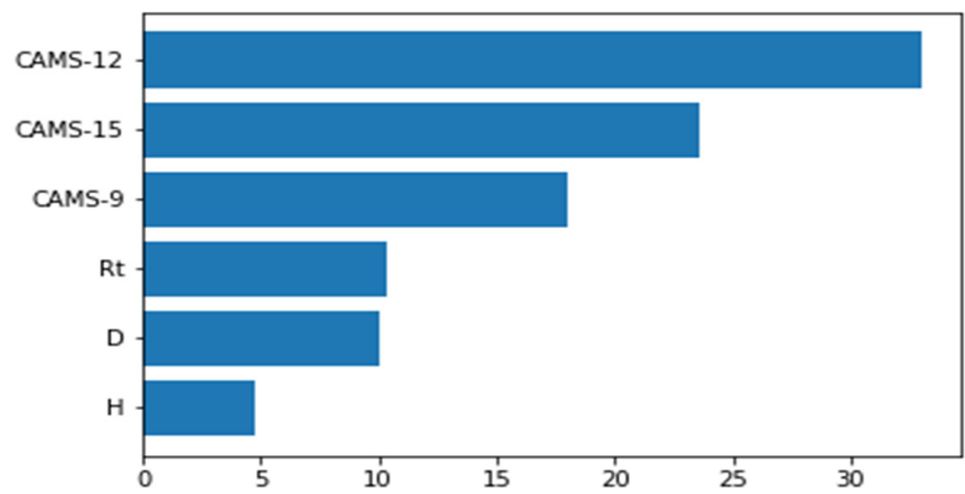

Figure 2. Mean importance scores (\%) of independent variables to AOD estimates for the space-time extremely randomized models.

\subsection{AOD Maps}

We used the optimized space-time models to predict the missing values in the daily MCD19A2 data of the study period. Then we used these predictions to fill the gaps in this product. The outputs of the previous processes were daily AOD maps with $1 \mathrm{~km}$ spatial resolution and full coverage over Europe for the period of March-June in the years 2015-2020. To analyze the COVID-19 lockdown effects on AOD levels, we calculated the average AOD levels for the months' March-June of the years 2015-2019 and compared these levels with the same period of the year 2020 (see Figure 3). Moreover, we generated daily AOD maps for the period of January 2018-June 2020 to validate GHADA through all seasons and not solely during the chosen lockdown months. 


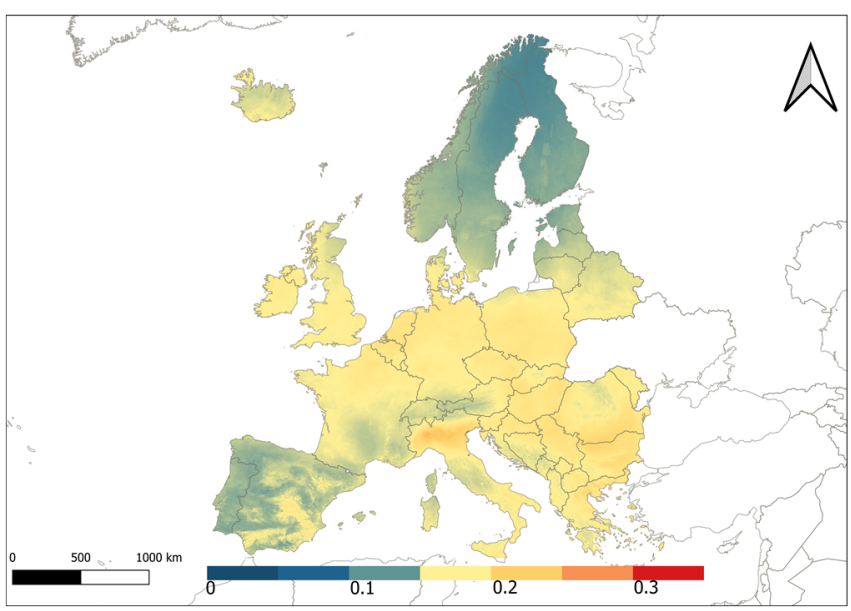

(a)

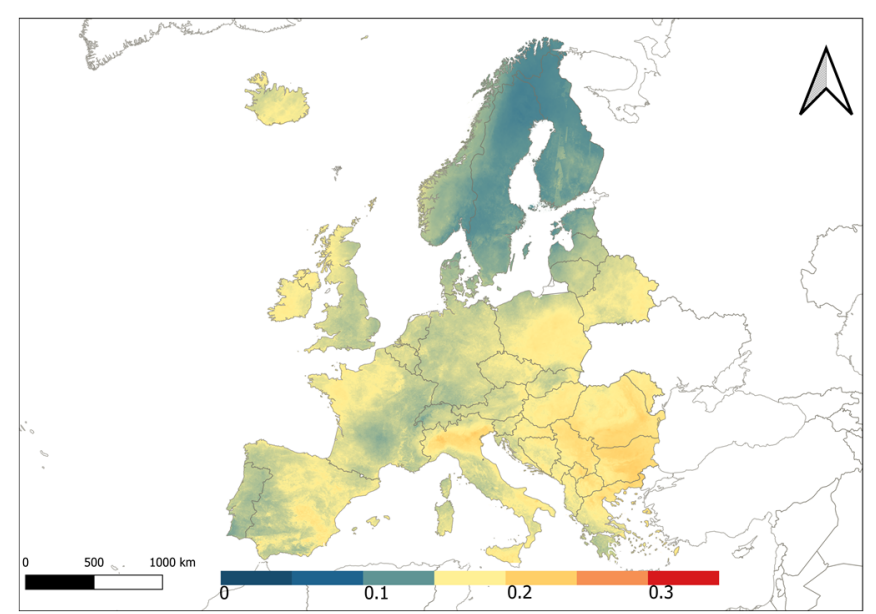

(b)

Figure 3. The average AOD values for the months March-June of (a) the years 2015-2019 and (b) of the year 2020 during the chosen lockdown period.

\subsection{Validation with AERONET}

With the assumption that the aerosol column is relatively uniform within a certain time-space boundary [41], the validation of satellite-based AOD products is usually performed between AOD retrievals within the spatiotemporal window and the corresponding AERONET observations [42]. An acceptable accuracy of AOD products can be achieved when $66 \%$ of retrievals fall within expected error envelopes (EE) $[23,43]$. We used for validation the average AERONET level 2.0 quality assurance observations between 10 a.m. and 2 p.m. from 57 stations across Europe during the period of January 2018-June 2020. We chose two spatial diameters, $20 \mathrm{~km}$ and $50 \mathrm{~km}$, with AERONET stations in the center for validation and statistical analysis that extensively uses root-mean-square error (RMSE), mean absolute error (MAE), expected error (EE) envelopes, and the fraction of AOD retrievals of the total number $(\mathrm{N})$ falling within EE envelope (Equations (9)-(13)).

$$
\begin{aligned}
\mathrm{RMSE} & =\sqrt{\frac{1}{N} \sum\left(A O D_{\text {GHADA }}-A O D_{\text {AERONET }}\right)^{2}} \\
\mathrm{MAE} & =\frac{1}{N} \sum\left|A O D_{\text {GHADA }}-A O D_{\text {AERONET }}\right| \\
\mathrm{Bias} & =\frac{1}{N} \sum\left(A O D_{\text {GHADA }}-A O D_{\text {AERONET }}\right) \\
\mathrm{EE} & = \pm\left(0.05+0.15 * \mathrm{AOD}_{\mathrm{AERONET}}\right) \\
\mathrm{AOD}_{\text {AERONET }}- & |\mathrm{EE}| \leq \mathrm{AOD}_{\mathrm{GHADA}} \leq \mathrm{AOD}_{\mathrm{AERONET}}+|\mathrm{EE}|
\end{aligned}
$$

The statistical analysis between daily GHADA maps and AERONET observations has shown similar validation results for the two chosen spatial diameters with $\sim 84 \%$ of the samples falling within the EE, good correlations $\mathrm{R} \sim 76-77 \%$, and relatively small RMSE $\sim 0.066-0.067$, refer to Table 3.

Table 3. Validation results of GHADA with AERONET at two spatial diameters, where $\mathrm{N}$ is the total number of sample points.

\begin{tabular}{ccccccc}
\hline $\mathbf{D}(\mathbf{K m})$ & $\mathbf{N}$ & $\mathbf{R}$ & MAE & RMSE & Bias & EE(\%) \\
\hline 20 & 10916 & 0.762 & 0.043 & 0.067 & -0.014 & 83.7 \\
50 & 12212 & 0.767 & 0.043 & 0.066 & -0.014 & 83.7 \\
\hline
\end{tabular}


Figure 4 represents the density scatter plots for the validation of AOD at $550 \mathrm{~nm}$ from GHADA with the AERONET stations at the two chosen spatial diameters.
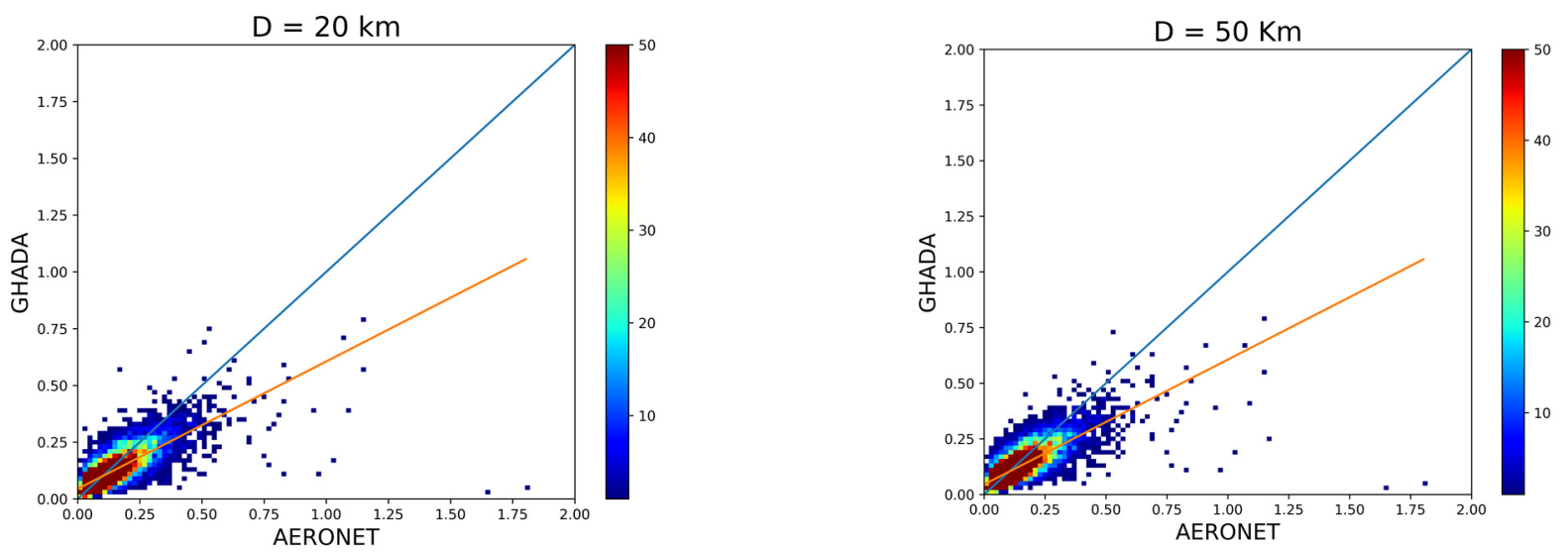

Figure 4. Density scatter plots of validation AOD at $550 \mathrm{~nm}$ from GHADA with 57 AERONET stations between 10 a.m. and 2 p.m. at two spatial diameters of $20 \mathrm{~km}$ and $50 \mathrm{~km}$. The colored scale bar stands for the frequency of occurrence.

\subsection{AOD Relative Percentage Difference}

The variations in AOD levels were calculated for each grid cell using the Relative Percentage Difference (RPD) Equation (14).

$$
\mathrm{RPD}=\frac{\mathrm{AOD}_{2020}-\mathrm{AOD}_{2015-2019}}{\mathrm{AOD}_{2015-2019}} * 100
$$

where $\mathrm{AOD}_{2020}$ is the mean $\mathrm{AOD}$ value in the study period of 2020 and $\mathrm{AOD}_{2015-2019}$ is the mean AOD value for the study period covering 2015-2019. The changes are presented in Figure 5.

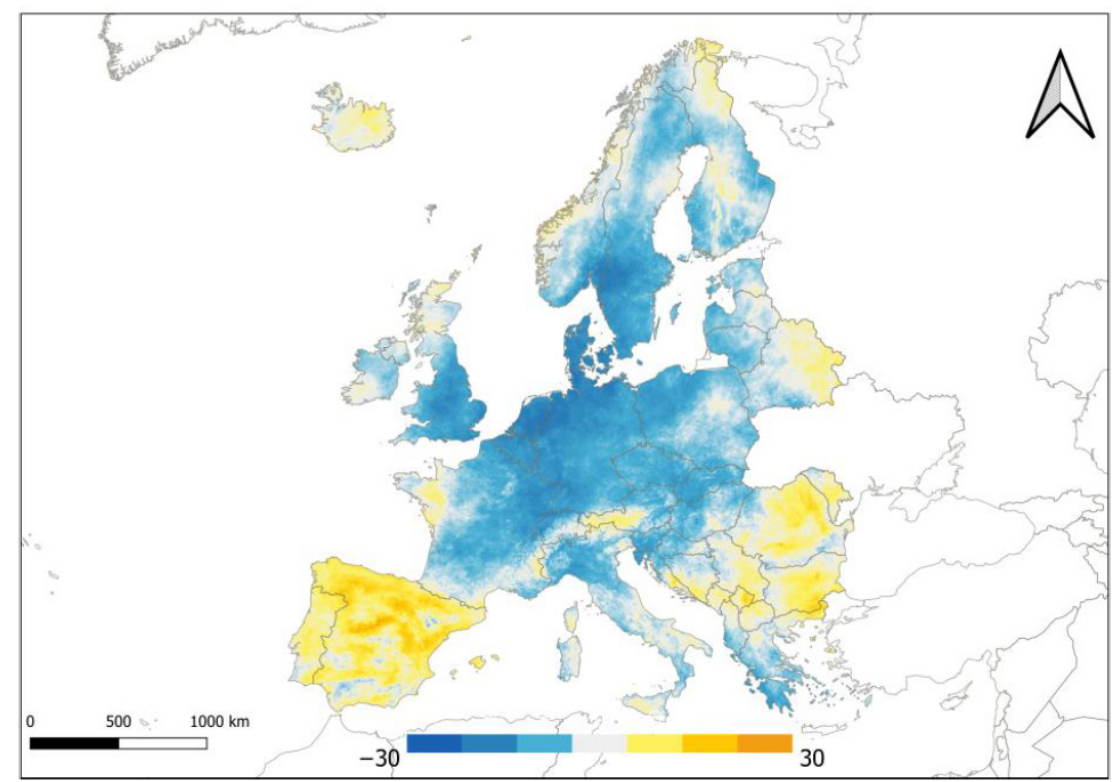

Figure 5. Relative percentage difference of AOD over Europe for the months March-June of the year 2020 and the same months of the previous 5 years.

\section{Discussion}

In this study, a machine learning-based scheme was used to overcome the limitations in time series analysis concerning AOD. A new dataset for AOD at $550 \mathrm{~nm}$ with full coverage over Europe and with $1 \mathrm{~km}$ spatial resolution (GHADA) was built. We trained an extra 
trees model for each year (2015-2020) using the MODIS MCD19A2 as the target variable and CAMS modeled AOD with improved spatiotemporal information as the independent variables. Results showed that the trained models had high accuracies ranging between

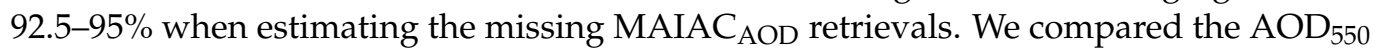
from GHADA and surface observations at 57 AERONET sites over Europe, with two spatial diameters around these AERONET stations within the period of January 2018-June 2020. The overall comparison with ground-based measurements showed a good correlation, with a bias as low as 0.014 and $\mathrm{R} \sim 0.76$. Then we used GHADA to study the influence of COVID-19 pandemic lockdown on AOD levels over Europe in the months March-June by comparing it to AOD levels in the same months for the past five years (2015-2019). The most important advantage of our study when compared to similar work is that we used daily full-coverage AOD maps with high spatial resolution when calculating the average AOD values before and after the lockdown. Such complete coverage reduces bias and uncertainty in such time-series analyses. As shown above, in Figure 5, we have found that AOD levels decreased by 10-30\% over most countries of the study area in 2020, mainly the countries located at the center of the analyzed area, while AOD levels increased over the countries that are located on the boundaries of the study area. In the west, AOD increased over Spain and Portugal; in the east, AOD increased over Romania, Bulgaria, Moldova, and Kosovo; in the north, the level slightly increased over Iceland. The decrease in AOD levels was the greatest in the Netherlands, with an average decrease of $20 \%$, while Spain had the highest average increase in AOD levels by $10 \%$. It must be noted that the five AERONET stations in Spain included in this study did not reflect the average increase in AOD over the whole country due to their limited spatial coverage.

As an attempt to justify the findings in areas of increased AOD, we investigated the relationship between the RPD in AOD for the months March-June of the year 2020 and the previous five years and the RPD for four meteorological variables (relative humidity, wind speed, surface temperature, and total precipitation) calculated for the times of MODIS satellites overpassing (10 a.m. to 2 p.m.). We found a close trend between relative humidity and AOD. Spain, Portugal, northern Norway, eastern Belarus, and southern Bulgaria had higher RPD in both AOD and relative humidity. Spain and Portugal had the highest increase of 10-23\% in relative humidity. In agreement, areas of decreased humidity had lower RPD of AOD; however, such correlation is to a lower extent than the effect of increased humidity. An exception to this finding is Romania, where RPD in humidity was decreased however AOD was increased. Regarding wind speed, RPD decreased by $\sim 18 \%$ in Spain and Portugal, where AOD had a significant increase. Also, the northern part of Italy and the western part of Austria had a clear inverse trend between AOD and wind speed. The average relative humidity over Spain was 65\% during the lockdown period of the year 2020. High relative humidity combined with a low average wind speed of less than $\sim 3 \mathrm{~m} / \mathrm{s}$ play an important role in increasing AOD. Our findings are consistent with [44], where they associated higher humidity and lower wind speed with higher AOD. We found no direct relationship between RPD of neither surface temperature nor total precipitation and RPD of AOD, all of which strengthens the argument that lowering AOD is a consequence of the lockdown. Although we proved that AOD levels increased over Spain, other pollutants such as $\mathrm{NO}_{2}$ were decreased, which is attributed to the difference in the source of these pollutants as discussed elsewhere [44]. Figure 6 shows the RPD of relative humidity and RPD of wind speed between the lockdown months of the year 2020 and the same period of the previous five years. 


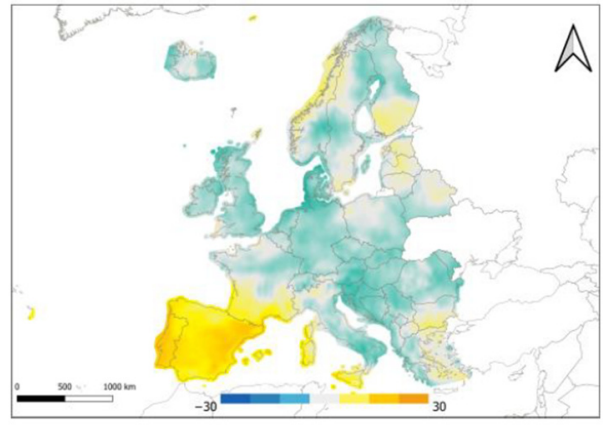

(a)

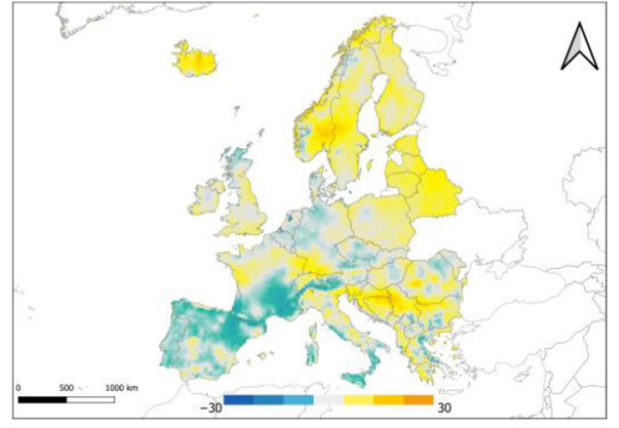

(b)

Figure 6. Relative percentage difference of (a) relative humidity and (b) wind speed over Europe between 10 a.m. and 2 p.m. for the months March-June of the year 2020 and the same months of the previous 5 years.

Nevertheless, it must be noted that the average AOD levels over Europe are relatively low $(\mathrm{AOD}<0.3)$ compared to other more polluted regions, where more prominent differences in AOD levels can be observed, for example, as published in [8] where AOD levels over India were investigated. In addition, the extent of restrictions imposed and the adherence to them may contribute to the significance of the change in AOD levels.

\section{Conclusions}

The advancement of machine learning algorithms provides solutions for AOD satellitebased data drawbacks such as low spatial resolution and gaps caused by persistent clouds, cloud contamination, and high surface reflectance and opens new horizons for studies that can influence decision making. A machine learning-based scheme was used to enhance time series analysis of AOD over the study period. Space-time extremely randomized trees models were built to fill the gaps in the MCD19A2 product of the moderate imaging spectroradiometer (MODIS). The output was a geo-harmonized atmospheric dataset for aerosol optical depth (GHADA) with complete coverage of $1 \mathrm{~km}$ spatial resolution over Europe. To the best of our knowledge, GHADA is the first dataset with this coverage and resolution for Europe, and we are the first to analyze how COVID-19 affected AOD levels over Europe with gaps-free AOD maps at high spatial resolution.

We compared AOD levels during the chosen lockdown period to the mean AOD values during the same period in the previous five years. We found a general decrease trend in the countries located at the center of the study area, with the Netherlands scoring the highest average decrease. In contrast, AOD levels increased in the eastern and western European countries as it is distinctly visible in Kosovo and Spain, respectively. We found a correlation between high humidity and low wind speed with AOD increase, which justifies such an increase in countries like Spain and Portugal. We excluded surface temperature and total precipitation as contributing factors to the detected changes in AOD levels, which in return makes COVID-19 lockdown the major cause for the decrease in AOD levels.

Once GHADA is made publicly accessible, it can be used to investigate air quality over Europe with $1 \mathrm{~km}$ spatial resolution and improve time series analysis, overcoming the gaps encountered during such studies. The lockdown that happened due to the pandemic generally lowered AOD levels; however, such lockdown is not the ultimate solution to control AOD levels. Cleaner sources of energy and road transport are needed to maintain lower levels of AOD and good air quality. Based on our obtained results, we recommend utilizing machine learning to solve time series analysis limitations and to conduct various applications concerning air quality.

Author Contributions: S.I. and L.H. conceptualized the work. S.I., M.L. and O.P. designed and implemented the workflow and processed the data. M.L., O.P., K.P. and L.H. contributed to the improvement of the draft manuscript. Saleem Ibrahim wrote the paper. All authors have read and agreed to the published version of the manuscript. 
Funding: This work is co-financed under Grant Agreement Connecting Europe Facility (CEF) Telecom project 2018-EU-IA-0095 by the European Union and by the Grant Agency of the Czech Technical University in Prague, grant No. SGS21/054/OHK1/1T/11.

Institutional Review Board Statement: Not applicable.

Informed Consent Statement: Not applicable.

Data Availability Statement: The data and data analysis methods are available upon request.

Acknowledgments: The authors sincerely thank NASA EOSDIS for providing the daily MODIS MAIAC AOD product (MCD19A2) available from the Land Processes Distributed Active Archive Center (LPDAAC), AERONET (https:/ / aeronet.gsfc.nasa.gov/) for providing AOD ground-based observation data (was last accessed in May 2021), the European Center for Medium-Range Weather Forecasts (ECMWF) for providing global reanalysis of atmospheric composition, and the Japan Aerospace Exploration Agency (JAXA) for providing the digital surface model used in this study.

Conflicts of Interest: Authors declare no conflict of interest.

\section{References}

1. Boffey, D. US Visitors Set to Remain Banned from Entering EU. Guardian 2020. Available online: https://www.theguardian.com/ world/2020/jun/29/us-visitors-set-to-remain-banned-from-entering-eu (accessed on 1 May 2021).

2. Henley, J.; Oltermann, P. More Than $250 \mathrm{~m}$ People Now in Lockdown in EU as Germany and Belgium Adopt Measures. Guardian 2020. Available online: https://www.theguardian.com/world/2020/mar/18/coronavirus-lockdown-eu-belgium-germanyadopt-measures (accessed on 1 May 2021).

3. Tobias, A.; Carnerero, C.; Reche, C.; Massague, J.; Via, M.; Minguillon, M.C.; Alastuey, A.; Querol, X. Changes in air quality during the lockdown in Barcelona (Spain) one month into the SARS-CoV-2 epidemic. Sci. Total Environ. 2020, 726, 138540. [CrossRef]

4. Muhammad, S.; Long, X.; Salman, M. COVID-19 pandemic and environmental pollution: A blessing in disguise? Sci. Total Environ. 2020, 728, 138820. [CrossRef]

5. Filonchyk, M.; Hurynovich, V.; Yan, H. Impact of COVID-19 lockdown on air quality in the Poland, Eastern Europe. Environ. Res. 2021, 198, 110454. [CrossRef] [PubMed]

6. Soni, M.; Verma, S.; Jethava, H.; Payra, S.; Lamsal, L.; Gupta, P.; Singh, J. Impact of COVID-19 on the Air Quality over China and India Using Long-term (2009-2020) Multi-satellite Data. Aerosol Air Qual. Res. 2020, 21, e200295. [CrossRef]

7. Filonchyk, M.; Hurynovich, V.; Yan, H.; Gusev, A.; Shpilevskaya, N. Impact Assessment of COVID-19 on Variations of SO 2 , NO 2 , CO and AOD over East China. Aerosol Air Qual. Res. 2020, 20, 1530-1540. [CrossRef]

8. Ranjan, A.K.; Patra, A.K.; Gorai, A.K. Effect of lockdown due to SARS COVID-19 on aerosol optical depth (AOD) over urban and mining regions in India. Sci. Total Environ. 2020, 745, e141024. [CrossRef] [PubMed]

9. Kalluri, R.O.R.; Gugamsetty, B.; Tandule, C.R.; Kotalo, R.G.; Thotli, L.R.; Rajuru, R.R.; Palle, S.N.R. Impact of aerosols on surface ozone during COVID-19 pandemic in southern India: A multi-instrumental approach from ground and satellite observations, and model simulations. J. Atmos. Sol. Terr. Phys. 2021, 212, 105491. [CrossRef]

10. Liu, Y.; Sarnat, J.A.; Coull, B.A.; Koutrakis, P.; Jacob, D.J. Validation of Multiangle Imaging Spectroradiometer (MISR) aerosol optical thickness measurements using Aerosol Robotic Network (AERONET) observations over the contiguous United States. J. Geophys. Res. 2004, 109. [CrossRef]

11. Shen, H.; Li, T.; Yuan, Q.; Zhang, H. Estimating Regional Ground-Level PM2.5 Directly from Satellite Top-of-Atmosphere Reflectance Using Deep Belief Networks. J. Geophys. Res. Atmos. 2018, 123, 13875-13886. [CrossRef]

12. Yang, Q.; Yuan, Q.; Yue, L.; Li, T.; Shen, H.; Zhang, L. The relationships between PM2.5 and aerosol optical depth (AOD) in mainland China: About and behind the spatio-temporal variations. Environ. Pollut. 2019, 248, 526-535. [CrossRef]

13. Zhang, H.; Hoff, R.M.; Engel-Cox, J.A. The relation between Moderate Resolution Imaging Spectroradiometer (MODIS) aerosol optical depth and PM2.5 over the United States: A geographical comparison by U.S. Environmental Protection Agency regions. J. Air Waste Manag. Assoc. 2009, 59, 1358-1369. [CrossRef]

14. Ajtai, N.; Mereuta, A.; Stefanie, H.; Radovici, A.; Botezan, C.; Zawadzka-Manko, O.; Stachlewska, I.S.; Stebel, K.; Zehner, C. SEVIRI Aerosol Optical Depth Validation Using AERONET and Intercomparison with MODIS in Central and Eastern Europe. Remote Sens. 2021, 13, 844. [CrossRef]

15. Torres, O.; Bhartia, P.K.; Sinyuk, A.; Welton, E.J.; Holben, B.N. Total Ozone Mapping Spectrometer measurements of aerosolabsorption from space: Comparison to SAFARI 2000 ground-based observations. J. Geophys. Res. 2005, 110. [CrossRef]

16. Torres, O.; Tanskanen, A.; Veihelmann, B.; Ahn, C.; Braak, R.; Bhartia, P.K.; Veefkind, P.; Levelt, P. Aerosols and surface UV products from Ozone Monitoring Instrument observations: An overview. J. Geophys. Res. 2007, 112. [CrossRef]

17. Sayer, A.M.; Hsu, N.C.; Bettenhausen, C.; Ahmad, Z.; Holben, B.N.; Smirnov, A.; Thomas, G.E.; Zhang, H. SeaWiFS Ocean Aerosol Retrieval (SOAR): Algorithm, validation, and comparison with other data sets. J. Geophys. Res. 2012, 117. [CrossRef]

18. Knapp, K.R.; Frouin, R.; Kondragunta, S.; Prados, A. Toward aerosol optical depth retrievals over land from GOES visible radiances: Determining surface reflectance. Int. J. Remote Sens. 2005, 26. [CrossRef] 
19. Lim, H.; Choi, M.; Kim, J.; Kasai, Y.; Chan, P.W. AHI/Himawari-8 Yonsei Aerosol Retrieval (YAER): Algorithm, Validation and Merged Products. Remote Sens. 2018, 10, e699. [CrossRef]

20. Kahn, R.A.; Gaitley, B.J.; Garay, M.J.; Diner, D.J.; Eck, T.F.; Smirnov, A.; Holben, B.N. Multiangle Imaging SpectroRadiometer global aerosol product assessment by comparison with the Aerosol Robotic Network. J. Geophys. Res. 2010, 115. [CrossRef]

21. Sun, L.; Wei, J.; Bilal, M.; Tian, X.; Jia, C.; Guo, Y.; Mi, X. Aerosol Optical Depth Retrieval over Bright Areas Using Landsat 8 OLI Images. Remote Sens. 2016, 8, 23. [CrossRef]

22. Levy, R.C.; Mattoo, S.; Munchak, L.A.; Remer, L.A.; Sayer, A.M.; Patadia, F.; Hsu, N.C. The Collection 6 MODIS aerosol products over land and ocean. Atmos. Meas. Tech. 2013, 6, 2989-3034. [CrossRef]

23. Remer, L.A.; Kaufman, Y.J.; Tanré, D.; Mattoo, S.; Chu, D.A.; Martins, J.V.; Li, R.-R.; Ichoku, C.; Levy, R.C.; Kleidman, R.G.; et al. The MODIS Aerosol Algorithm, Products, and Validation. J. Atmos. Sci. 2005, 62, 947-973. [CrossRef]

24. Hsu, N.C.; Jeong, M.J.; Bettenhausen, C.; Sayer, A.M.; Hansell, R.; Seftor, C.S.; Huang, J.; Tsay, S.C. Enhanced Deep Blue aerosol retrieval algorithm:The second generation. J. Geophys. Res. 2013, 118, 9296-9315. [CrossRef]

25. Hsu, N.C.; Tsay, S.; King, M.D.; Herman, J.R. Aerosol Properties Over Bright-Reflecting Source Regions. IEEE Trans. Geosci. Remote Sens. 2004, 42, 557-569. [CrossRef]

26. Lyapustin, A.; Wang, Y.; Laszlo, I.; Kahn, R.; Korkin, S.; Remer, L.A.; Levy, R.; Reid, J.S. Multiangle implementation of atmospheric correction (MAIAC): 2. Aerosol algorithm. J. Geophys. Res. 2011, 116. [CrossRef]

27. King, M.D.; Platnick, S.; Menzel, W.P.; Ackerman, S.A.; Hubanks, P.A. Spatial and Temporal Distribution of Clouds Observed by MODIS Onboard the Terra and Aqua Satellites. IEEE Trans. Geosci. Remote Sens. 2013, 51, 3826-3852. [CrossRef]

28. Meraner, A.; Ebel, P.; Zhu, X.X.; Schmitt, M. Cloud removal in Sentinel-2 imagery using a deep residual neural network and SAR-optical data fusion. ISPRS J. Photogramm. Remote Sens. 2020, 166, 333-346. [CrossRef]

29. Yang, J.; Hu, M. Filling the missing data gaps of daily MODIS AOD using spatiotemporal interpolation. Sci. Total Environ. 2018, 633, 677-683. [CrossRef]

30. Schneider, R.; Vicedo-Cabrera, A.M.; Sera, F.; Masselot, P.; Stafoggia, M.; de Hoogh, K.; Kloog, I.; Reis, S.; Vieno, M.; Gasparrini, A. A Satellite-Based Spatio-Temporal Machine Learning Model to Reconstruct Daily PM2.5 Concentrations across Great Britain. Remote Sens. 2020, 12, 3803. [CrossRef]

31. Open Data Science Europe. Geo-Harmonizer Project Implementation Plan 2020-2022; Open Data Science Europe: Wageningen, The Netherlands, 2020.

32. Lyapustin, A.; Wang, Y.; Korkin, S.; Huang, W. MODIS Collection 6 MAIAC algorithm. Atmos. Meas. Tech. 2018, 11, 5741-5765. [CrossRef]

33. Lyapustin, A.; Wang, Y.; Laszlo, I.; Korkin, S. Improved cloud and snow screening in MAIAC aerosol retrievals using spectral and spatial analysis. Atmos. Meas. Tech. 2012, 5, 843-850. [CrossRef]

34. Inness, A.; Ades, M.; Agustí-Panareda, A.; Barré, J.; Benedictow, A.; Blechschmidt, A.; Dominguez, J.J.; Engelen, R.; Eskes, H.; Flemming, J.; et al. The CAMS reanalysis of atmospheric composition. Atmos. Chem. Phys. 2019, 19, 3515-3556. [CrossRef]

35. Tadono, T.; Ishida, H.; Oda, F.; Naito, S.; Minakawa, K.; Iwamoto, H. Precise Global DEM Generation by Alos Prism. ISPRS Ann. Photogramm. Remote Sens. Spat. Inf. Sci. 2014, 2, 71. [CrossRef]

36. Holben, B.N.; Eck, T.F.; Slutsker, I.; Tanré, D.; Buis, J.P.; Setzer, A.; Vermote, E.; Reagan, J.A.; Kaufman, Y.J.; Nakajima, T.; et al. AERONET-A Federated Instrument Network and Data Archive for Aerosol Characterization. Remote Sens. Environ. 1998, 66, 1-16. [CrossRef]

37. Holben, B.N.; Tanre, D.; Smirnov, A.; Eck, T.F.; Slutsker, I.; Abuhassan, N.; Newcomb, W.W.; Schafer, J.S.; Chatenet, B.; Lavenu, F.; et al. An emerging ground-based aerosol climatology: Aerosol optical depth from AERONET. J. Geophys. Res. 2001, 106, 12067-12097. [CrossRef]

38. Ångström, A. The parameters of atmospheric turbidity. Tellus 1964, 16, 64-75. [CrossRef]

39. Geurts, P.; Ernst, D.; Wehenkel, L. Extremely randomized trees. Mach. Learn. 2006, 63, 3-42. [CrossRef]

40. Wei, J.; Li, Z.; Cribb, M.; Huang, W.; Xue, W.; Sun, L.; Guo, J.; Peng, Y.; Li, J.; Lyapustin, A.; et al. Improved 1 km resolution PM2.5 estimates across China using enhanced space-time extremely randomized trees. Atmos. Chem. Phys. 2020, 20, 3273-3289. [CrossRef]

41. Anderson, T.L.; Charlson, R.J.; Winker, D.M.; Ogren, J.A.; Holmén, K. Mesoscale Variations of Tropospheric Aerosols. J. Atmos. Sci. 2003, 60, 119-136. [CrossRef]

42. Martins, V.S.; Lyapustin, A.; de Carvalho, L.A.S.; Barbosa, C.C.F.; Novo, E.M.L.M. Validation of high-resolution MAIAC aerosol product over South America. J. Geophys. Res. Atmos. 2017, 122. [CrossRef]

43. Levy, R.C.; Remer, L.A.; Kleidman, R.G.; Mattoo, S.; Ichoku, C.; Kahn, R.; Eck, T.F. Global evaluation of the Collection 5 MODIS dark-target aerosol products over land. Atmos. Chem. Phys. 2010, 10, 10399-10420. [CrossRef]

44. Acharya, P.; Barik, G.; Gayen, B.K.; Bar, S.; Maiti, A.; Sarkar, A.; Ghosh, S.; De, S.K.; Sreekesh, S. Revisiting the levels of Aerosol Optical Depth in south-southeast Asia, Europe and USA amid the COVID-19 pandemic using satellite observations. Environ. Res. 2021, 193, 110514. [CrossRef] [PubMed] 